\title{
DuPont Model: A Tool Promotes System Thinking and Integration in Undergraduate Business Education
}

\author{
Shenghan Xu (Corresponding author) \\ Dept. of Business, College of Business and Economics \\ University of Idaho \\ 875 Perimeter Drive MS3161, Moscow, Idaho 83844-3161, United States \\ Tel: 1-208-885-1083Ｅ-mail: shenghan@uidaho.edu \\ Mark Rounds \\ Dept. of Business, College of Business and Economics \\ University of Idaho \\ 875 Perimeter Drive MS3161, Moscow, Idaho 83844-3161, United States
}

Received: October 30, 2018 Accepted: December 28, 2018 Published: January 8, 2019

doi:10.5296/ijafr.v9i1.14199

URL: https://doi.org/10.5296/ijafr.v9i1.14199

\begin{abstract}
The increasingly complex world of commerce has forced business schools to focus on preparing students for a new environment that requires systemic thinking, the ability to work in teams and the skill and motivation needed to respond to rapid change. Unfortunately, little has changed in how we educate future business leaders. In this paper we report the preliminary results of an attempt to increase under graduate students' levels of cross-functional and systemic thinking using the DuPont model to integrate across the traditional functional areas of information systems and operations management). The model provides a valuable framework for educators, and can be used to display how typical functional-area tasks (e.g., determining capital structure) are related to firm-level outcomes (e.g., return on equity), and how decision making in one functional area (e.g., managing inventory) has a similar impact on firm-level outcomes as decisions made in other functional areas (e.g., managing cash).
\end{abstract}

Keywords: DuPont model, Business education, Integration, System thinking 


\section{Introduction}

For some time now, employers, advisory boards, academics and others have called for improvements in business education outcomes. In particular, business schools have been asked to help prepare students to function in enterprises that require systemic thinking (Mingers, 2015) cross-functional perspectives (Lorange, Rembiszewski, 2015, Godfrey, Illes, \& Berry, 2005; AACSB, 1996), the ability to work in cross functional teams (Chiang \& Lundgren, 2017) (Bolton, 1999), and the skill and motivation needed to respond to rapid change (McMurray, Dutton, McQuaid, \& Richard, 2016). Others have suggested that management education should be organized around "the nature of managerial work, not the functions worked on" (Mintzberg \& Gosling, 2002). Unfortunately, despite these calls for changing the skills and knowledge that graduates possess, and the behaviors they exhibit, little has changed in how we educate future business leaders.

In most business undergraduate programs, core curriculum topics are normally taught by individual functional experts in stand-alone functionally-discrete courses. As a consequence, most students spend the bulk of their time focused on their functional area with integration taught at the end in a cap stone strategy course. This result in business graduates who are prepared to be "entry-level cogs in a machine" (Godfrey, et al, 2006), but not future managers who are prepared for a "whole career" (Gordon \& Howell, 1959).

Much of the change that we have seen in business education is on the margins, partly because many business schools recognize that curriculum integration is an extensive and potentially disruptive curricular change that may involve cost and is fraught with pitfalls (Athavale, et. al., 2010). Some of the practices such as individual professors add integration-oriented cases, activities and exercises to a specific course, but which are isolated from changes that may or may not be occurring in other courses. As another alternative, colleges implement passive cross-functional connections between courses (e.g., coordinating syllabi, a common theme) without changing the nature of professor job requirements or the silo-reinforcing program and reward structures that exist in most colleges of business. Our own Business 490 course at the University of Idaho is the result of such action where integration is taught only after the specific discipline-based knowledge has been acquired by the student.

There have been several integrated, team-taught programs at the undergraduate level (Pharr, Morris, Stover, Byers \& Reyes, 1998) and further described in Pharr, 2000, but these programs are resource intensive and are most appropriate in settings with full-time students who can be organized into cohort groups. Other educational institutions have emphasized double and triple majors as a means to achieve these ends (Berrett, 2013). Programs that serve non-residential, online, and part-time students or programs that rely on graduate teaching assistants to serve the needs of large sections in traditional classes in business schools would be hard pressed to implement an integrated, team-taught program.

In this manuscript, we describe how the DuPont Model can be used as a powerful integrating tool, with minimal training and coordination among diverse faculty. The model provides an excellent visual representation of the relationship for many functional area decisions (e.g., how much inventory to hold, how much cash to have on hand, the type of promotional 
campaign to use) and firm-level outcomes (e.g., return on equity, return on assets). And, because this model is relatively easy to explain, a student can be introduced or reintroduced to the model in any course and almost any level, from freshman to senior. Thus, it is not necessary to restrict students to a sequence of courses. In any given class, there may be students who have seen the model in other courses or students who are seeing the model for the first time. Furthermore, over the course of the program integration comes once a student sees the model applied in all of the functional areas (e.g., noticing that cash management is nearly identical to inventory management).

The paper is organized into three sections. The first section describes the DuPont Model, its history, structure, and how to apply it. In an effort to highlight how the model can be used to achieve some level of integration, the second section describes specific examples of how the model can be used in two standard business-principles courses (i.e., Management Information Systems and Supply Chain Management). However, the basic concept can be extended to multiple disciplines.

Finally, we discuss some ways that the model can be used to integrate across majors, to explain the corporate level implications of some emerging trend or regulation changes, in addition to functional area integration.

\section{Theoretical Background}

The topic of integrated curriculum has been an interest in the academia since the turn of the $20^{\text {th }}$ century (Drake and Burns, 2004). Across multiple disciplines no consensus has been reached in terms of the definition of integration. Drake and Burns (2004) loosely defined it as about making connections. They further illustrated three different approaches to integration, namely multidisciplinary, interdisciplinary and transdisciplinary integrations. In their view, the multidisciplinary approaches focus primarily on the intra-discipline integration. The inter-discipline approach focuses on the common learning across disciplines. And the transdisciplinary approach focuses on student questions and concerns. While discussion integrating sustainability in management education, Raufflet (2013) gave the integration in four distinct forms, which are discipline-based integration, strategic/competitive based integration, integration by application as well as systemic integration. In this manuscript, our method falls to the category of integration by application, in which managerial and business tools from disciplines are applied so as to contribute to building the connection and linkage among multiple disciplines. Shaidullina et. al (2015) provided a classification of integration types in education. They believe that integration is a system formation that combines procedural and resulting components contribution to the appearance of a system's new integrative quality. Their theoretical justification on the types of integration is based on quality characteristics of an integrated system or based on the presence of necessary components of an integrated system or based on temporal characteristics or based on the types of integrating subjects. Even though we believe the general application of integration falls more on the correlation and connection, we appreciate the clear theoretical classification and justification provided in the article. 


\section{MIMacrothink}

International Journal of Accounting and Financial Reporting

ISSN 2162-3082

2019, Vol. 9, No. 1

The use of financial ratios by various business professionals and small business owners to understand the scope of various business problems and has been acknowledged in the literature (c.f., Burson, 1998; Devine \& Seaton, 1995; Osteryoung \& Constand, 1992). The concepts of Return on Assets (ROA) and Return on Equity (ROE) are important for understanding the nature of profitability of a business enterprise. Specifically, a "return on" ratio illustrates the relationship between profits and the investment needed to generate them. However, these concepts are often "too far removed from normal activities" to be understood and useful to many managers or small business owners (Slater \& Olson, 1996).

In 1918, four years after he was hired by the Du Pont Corporation to work in its treasury department, electrical engineer F. Donaldson Brown was tasked with untangling the finances of General Motors which Du Pont had just purchased 23 percent the stock. Brown recognized that mathematical relationships existed among three regularly used ratios: 1) net profit margin (obviously a profitability measure), 2) total asset turnover (an efficiency measure), and 3) ROA. The product of net profit margin and total asset turnover equals ROA, and became the original Du Pont model, as illustrated in (Figure 1).

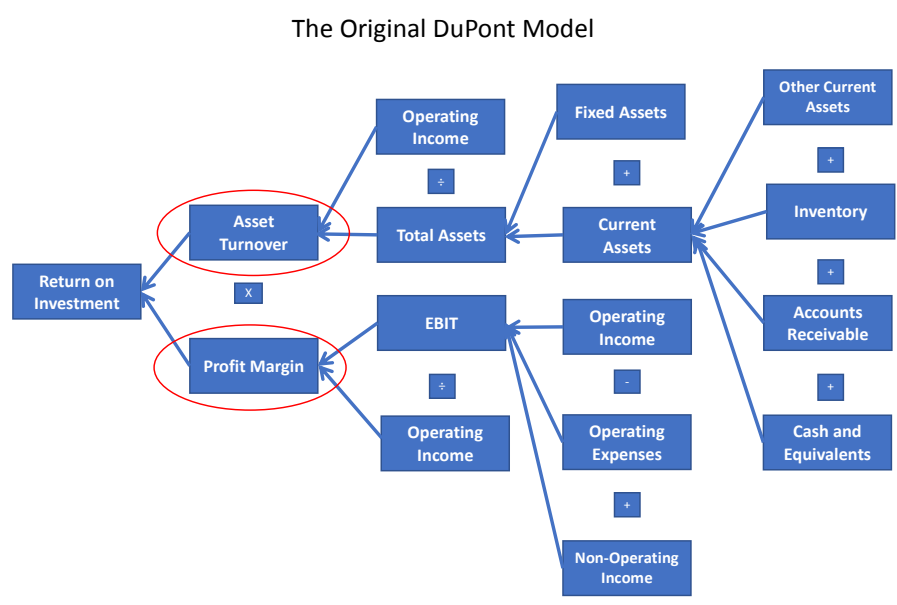

Figure 1. The original DuPont model

In the 1970s the generally accepted goal of financial management became "long term maximization return to the firm's owners" (Gitman, 1998) and focus shifted from ROA to ROE. This led to the first major modification of the original Du Pont model (Liesz, 2002). In addition to profitability and efficiency, the way in which a firm financed its activities (i.e. its use of leverage) became a third area of attention for financial managers. The new ratio of interest was called the equity multiplier, which equals total assets divided by equity. The modified DuPont model in the Microsoft Excel format is shown in (Figure 2). 


\section{Macrothink}
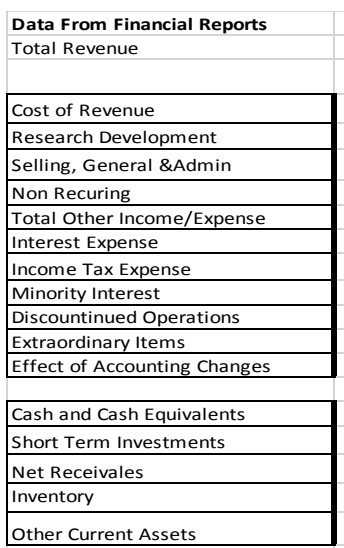

Other Current Assets

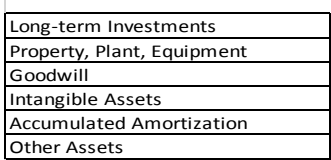

Other Assets

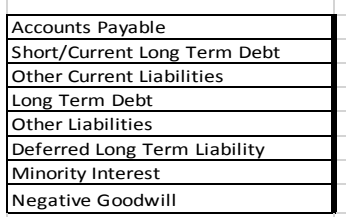

Redeemable Perferred Stock
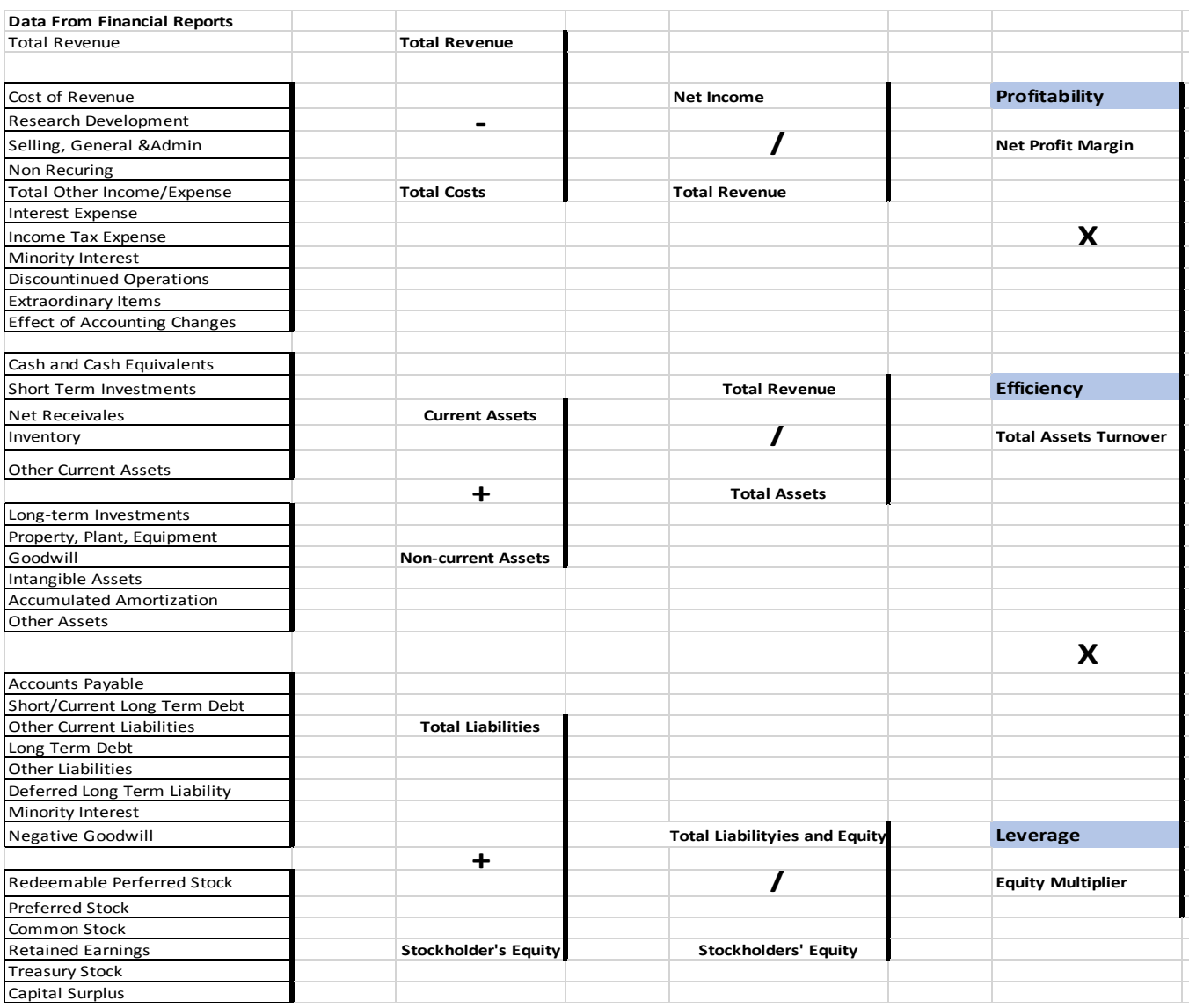

Figure 2. Extended three steps DuPont model

As a diagnostic tool the modified Du Pont Model can be used to compare the profitability, efficiency and leverage of peer firms, or to compare the performance of a single company from one year to the next. In addition, the model can be used to highlight how functional area decisions (i.e., things on the left side of the model) can impact profitability, efficiency, leverage, ROA, and ROE (i.e., things on the right side of the model). DuPont model provides a great tool to implement the integration by application approach, or episodic integration practices.

\section{Research Method}

In this section, we demonstrate an episodic integration practice that can be adopted in any business discipline teaching, as discussed in (Eveleth, et. al, 2011). As the business world evolves, new practice and business models emerge. We use some emerging concepts and examples (such as supply chain finance) in both supply chain management and information system management discipline to further demonstrate the use of DuPont model in classroom settings in introducing those new concept and practices. With the discussion revolved around the three major elements of the basic DuPont Model, i.e. the efficiency, the profitability and the leverage. We use some of the typical and up to date scenarios in the disciplines and discuss the financial impact of those decisions using the DuPont Model framework. 


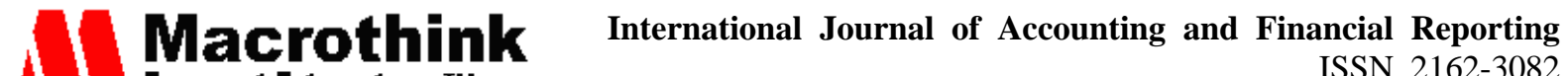 Institute"'

\subsection{Using DuPont Model to Discuss Supply Chain Finance}

Supply chain management (SCM) is a business field that focuses on efficiently integrate suppliers, manufacturers, warehouses, and stores, so that merchandise is produced and distributed at the right quantities, to the right locations, and at the right time, in order to minimize system-wide costs while satisfying service level requirement (Simchi-Levi, Kaminsky and Simchi-Levi, 2003). Research and practice in the supply chain field extends beyond the traditional corporate boundary to include the interactions with up-stream suppliers and down-stream retailers. Among those interactions, the efficient flow of information, merchandise, and finance were underscored as the epitome of well managed supply chain. It is well documented through many business success stories such as Sport Obermeyer, a supplier of fashion skiwear; Amazon, an ecommerce company, that SCM can not only contribute to the improvement in sales, reduction of cost of sales, but also accelerates the return of invested capital.

Traditionally, Supply Chain Management (SCM) has been a collection of various aspects, with influences from logistics and transportation, operations management and materials and distribution management, marketing, as well as purchasing and information technology (Jain, Dangayach, Agarwal and Banerjee, 2010). One of the fundamental understanding in supply chain is that consumers' buying behavior drives the underlining supply chain (Chopra and Meindl, 2016). Fisher's (1997) avant-garde article profoundly influenced the literature in the field by suggesting a framework which matches product type, which alludes to the buying behavior, with supply chain strategies. Many researchers listed various competitive capabilities for companies to achieve supply chain success, namely cost, quality, flexibility, and delivery (Wheelwright, 1984, Fine and Hax, 1985, Swink and Way, 1995). Increasingly fierce business competitions also prompted Lee (2004) to suggest the Triple-A supply chain, which focuses on agility (quick response to short-term changes in demand or supply); adaptability (adjusting design to accommodate market changes) and alignment (improvement of the entire chain). Christopher and Towill (2001) also emphasized the importance of supply chain by stating that it is supply chains compete not companies.

In the last three decades, the accelerated globalization has lengthened supply chains geographically to across multiple continents, with increased complexity of more partners and more transactions. The elongated supply chain reduced transactional visibility and created challenge in maintaining right amount of working capital to ensure cash flow. The regulatory changes in trade finance along with the advancing of financial technology (Fin-Techs) incubated the supply chain finance (Figure 3). 


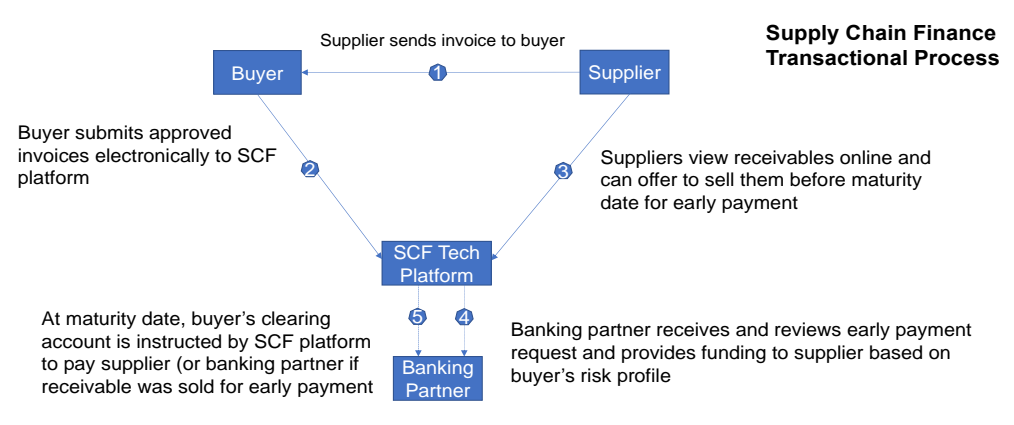

Adapted from Prime Revenue; McKinsey analysis

Figure 3. Supply chain finance process flow

\subsubsection{Supply Chain Finance}

Supply Chain Finance, also known as supplier finance or reverse factoring, is a set of solutions that optimizes cash flow by allowing buyers to extend supplier payment terms. It is a way to optimize working capital, reduce supply chain risk and allow businesses to increase supplier payment terms and while giving them the option to get paid early (Prime Revenue, 2017). On the supply chain finance platform, participants include buyers, suppliers, funders and platform providers. In most settings, buyers are large corporations that rely on many suppliers to provide goods and services. Buyers operate on a global basis and tend to have relatively easier and cheaper credit line. Suppliers provide goods and services to buyers. Suppliers also have their suppliers that forms supply chain or supply network. Funders are banks or non-bank investment capitals that advance funds to cover the cost approved supplier invoices. Platform providers are mostly cloud-enable technology solution providers that facilitate the supply chain finance ecosystem. There are two primary methods of implementing supply chain finance. The first one is buyer extends payment terms with all suppliers. In this case, the buyer could request an extended payment term, for example, from 60 -day payment to 120-day payment. By doing so, the buyer gains 60 days of account payable, which can be used as working capital to fund other activities. The buyer is the clear beneficiary of this practice. And the second one is suppliers get paid early by selling their invoices. This practice typically requires the buyer to set up a supply chain finance platform, on which the buyer invite target suppliers to participate in selling their invoices to financial institute of identified funders. Through this type of program, the supplier can get paid early to meet its cash flow needs. A small fee may be charged to the supplier during the invoice trading.

Given the focus of cash flow, supply chain finance and its impact on buyer or supplier's financial performance can be described more effectively using the DuPont Model. In the first case, when the buyer extends payment terms with all the suppliers, its financial performance as shown in DuPont model is as the following:

Efficiency (as measured by Total Asset Turnover): By extending the payment term from 60 days to 120 days, the account payable will be reduced, which indicates an increase in 
working capital, and a reduction in total liability. Since total asset is equal to total liability plus ending net worth, assuming the new purchase has transformed to new sales and some additional profit, asset turnover ratio will increase.

Leverage (as measured by the Equity Multiplier): New purchase can be translated into new sales and additional profit. As we discussed in asset turnover ratio, delayed payment will increase total asset, therefore, the equity multiplier will increase.

Profitability (as measured by Net Profit Margin): New purchase can be translated into new sales. Because of the delayed payment for the new purchase, there will be less interest to pay. That is, the net profit increases along with increases in sales. The end result on the profitability can be hard to decide and requires case by case analysis.

Through the above analysis, it has shown that the main benefit of delayed payment lies in the increase of efficiency and leverage. Its impact on profitability cannot be revealed easily as both the numerator and denominator of the equation are both changed simultaneously.

In the second case, when a supplier trades its invoice to get paid quickly, its financial performance as shown in DuPont model is as the following:

Efficiency (as measured by Total Asset Turnover): By getting the payment quickly, the supplier converts inventory into account receivable, later into cash and cash equivalent quickly. This practice increases sales and current assets. Since the increase in sales will be larger than the increase from current assets (i.e. sales include profit), the asset turnover ratio increases.

Leverage (as measured by the Equity Multiplier): By getting payment quickly, total assets increase through the increased current assets. Therefore, equity multiplier increases.

Profitability (as measured by Net Profit Margin): The end result on the profitability can be hard to decide and requires case by case analysis.

Through the above analysis, it has shown that the main benefit of supplier receiving fast payment lies in the increase of efficiency and leverage. Its impact on profitability cannot be revealed easily and may require case by case analysis.

\subsection{Using DuPont Model to Discuss Management Information Systems Examples}

In introductory management information system textbooks (Reilly and Gupta, 2015, Laudon and Laudon, 2018), common learning objectives focus on deployment and implementation of new systems, as well as how these systems affect other entities. Common threads include the move to e-commerce, the safeguarding of privacy and privileged information, e-commerce, and the growing use of databases.

Both texts discuss at some length the acquiring and justification of information systems and applications. A common thread is how to communicate technical concepts to a non-technical (but knowledgeable and motivated) management. The DuPont model provides a common language that allows practitioners from varied disciplines to make decisions. For example: Assume there is a prosperous brick-and-mortar firm that has been doing business for a 
number of years in a medium sized city. The company has saturated the market in its surrounding geographical area. In order to grow, the firm is examining selling its product on-line.

This would require management to decide whether to: 1) purchase servers and high-speed network connections, and develop the technical expertise in-house, or 2) to engage a competent web hosting company handle the e-commerce portion of the business and focus on their core competencies which have led to previous success of the firm.

To develop this initiative in-house would require the hiring of technical personnel, the procurement hardware/software, and then a significant time lag while the new systems and employees were brought on line and an e-commerce site was developed. During this time there would be no new revenue for the company and a significant increase in expenditure.

Hiring out this procedure to a web hosting company would mean a faster development cycle and a faster initial return, but higher long-term costs. Using the DuPont model as a framework, we can show the pluses and minuses of developing an on-line presence in-house. The figure below shows the financial changes that would occur in the company over the short term if they were to develop the system in-house.

To acquire the new equipment and software to develop this system in house, there would be a significant cash outlay, so a loan would have to be obtained. This would increase Long Term Debt, and increase Property, Plant and Equipment. There would also be an increase in Interest Expense and Selling, General and Administrative Expenses for the salaries of the technical personnel. There would be a period of perhaps six months to a year until these new changes would develop the revenue, so the result is as discussed below.

Efficiency (as measured by Total Asset Turnover): Total Assets would increase because of an increase in the size of the physical plant. This increase reduces Total Asset Turnover.

Leverage (as measured by the Equity Multiplier): Leverage increases due to the loan required to finance the increase in physical plant.

Profitability (as measured by Net Profit Margin): Increases in General, Selling and Administrative Expense and interest, without an increase in revenue, means that Net Profit Margin would fall.

Once the initial expenses have been paid off, the steady state (when revenue develops) would be:

Efficiency (as measured by Total Asset Turnover): Total Assets increase because of the increase in physical plant. This increase would continue reduce Total Asset Turnover.

Leverage (as measured by the Equity Multiplier): Leverage increased as the required loan is put in place.

Profitability (as measured by Net Profit Margin): General, Selling and Administrative Expense and interest increase. There is the potential increase to revenue which could be very large and cause the desired goal of increasing Net Profit Margin. 
Should the company decide to subcontract this effort to an IT provider, there would be a significant increase in Selling, General and Administrative Expenses, followed by a significantly quicker increase in Revenue. This is detailed below:

Efficiency (as measured by Total Asset Turnover): There is no change in the asset base of the company. Since revenue potentially improves with the addition of an e-commerce initiative, efficiency is also likely to improve.

Leverage (as measured by the Equity Multiplier): Leverage does not change as there is no investment and limited lag time to start this up.

Profitability (as measured by Net Profit Margin): General, Selling and Administrative Expense and interest both increases. There is a potential increase to revenue which could be very large and cause the desired goal of increasing the Net Profit Margin. The remaining discussion would focus on time value of money, where the various cash flows are discussed. The use of the DuPont Model makes the critical issues such as schedule and development cost very clear to the non-IT professional.

\section{Discussion and Future Work}

Through sample problems in two business principle areas, we have demonstrated that DuPont model provides visual and theoretical augmentation to the discipline specific instructions by providing a uniformed platform with consistent and easy to understand measurements (i.e. Profitability, Efficiency and Leverage Multiplier). Various business tactical and operational activities and their impact on firm level result are evident via dissecting the decisions into these three key elements, i.e. profitability, efficiency and leverage multiplier. In addition, we firmly believe and also as evident through our pedagogical practice that students presented with DuPont model in multiple settings with problems originated in different principle areas are better equipped with a holistic understanding of business system dynamics. The business silos can be mitigated, and cross-discipline knowledge can be imparted in a seemingly effortless format. In our pedagogical practice, we distribute the spreadsheet of the DuPont model template and let students to change variables and problems in class followed by class discussion. It proofed to be a well-received hands-on classroom experience for the tech savvy generation of business students.

In terms of future practice and research directions, we believe that developing some cohesive and comprehensive business cases and applying DuPont Model for the analysis will be conducive in enhancing business system view in students. Over the years, business research field also extended the three-step DuPont Model to a five-step one. The three-step model is the one we have used in this paper. The five -step method of DuPont model is an extension of the three-step model. In addition to the decomposed ROE to include profitability, efficiency and leverage multiplier, the five-step model also reveal how tax impact of the overall ROE. Given that new tax law will be in effect in the coming tax season in the April of 2019, it will be relevant to use the five-step model to show how the tax reduction affects ROE. 


\section{MlMacrothink}

International Journal of Accounting and Financial Reporting

ISSN 2162-3082 2019, Vol. 9, No. 1

\section{References}

Athavale, M., Davis, R., \& Myring, M. (2008). The integrated business curriculum: an examination of perceptions and practices. Journal of Education for Business, 83(5), 295-301.

Belch, G., \& Belch, M. (2009). Advertising and promotion: an integrated marketing communication perspective (8th ed.). McGraw-Hill.

Berrett, D. (2013). Double majors produce dynamic thinkers, study finds. The Chronicle of Higher Education. Retrieved from http://chronicle.com/article/Double-Majors-Produce-Dynamic/137917

Bolton, M. K. (1999). The role of coaching in student teams: A "just-in-time" approach to learning. Journal of Management Education, 23(3), 233-250.

Campbell, N. D., Heriot, K. C., \& Finney, R. Z. (2006). In defense of silos: An argument against the integrative undergraduate business curriculum. Journal of Management Education, 30(2), 316-332.

Chapman, S. N. (1989). Just-in-time supplier inventory: An empirical implementation model. International Journal of Production Research, 27(12), 1993-2007.

Chiang, J., \& Lundgren, A. (2017). What is the evolution of flexible work in corporations and what are the key trends?. Retrieved July 30, 2018, from http://digitalcommons.ilr.cornell.edu/student/168

Chopra, S., \& Meindl, P. (2016). Supply chain management, strategy, planning, and operation (6th ed.). London United Kingdom: Pearson.

Christopher, M., \& Towill, D. (2001). An integrated model for the design of agile supply chains. International Journal of Physical Distribution and Logistics Management, 31(4), 235-246.

Dalrymple, D. J. (1987). Sales forecasting practices: results from a United States survey. International Journal of Forecasting, 3(3-4), 379-391.

Dehning, B., \& Richardson, V. J. (2002). Returns on investments in information technology: A Research Synthesis. Journal of Information Systems Management, 16(1).

Drake, M. S., \& Burns, R. C. (2004). Meeting standards through integrated curriculum. Association for Supervision and Curriculum Development. Retrieved December 21, 2018, from

http://www.ascd.org/publications/books/103011/chapters/what-is-integrated-curriculum.aspx on.

Eveleth, D., Liesz, T., O'Malley, K., Rounds, M., \& Xu, S. (2011, July). DuPont Model: Integrating the Traditional Business Functional Areas. International Research Journal of Applied Finance, 2(7), 753. 


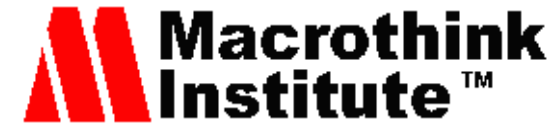

International Journal of Accounting and Financial Reporting

ISSN 2162-3082

2019, Vol. 9, No. 1

Fine, C. H., \& Hax, A. C. (1985). Manufacturing strategy: a methodology and an illustration. Interfaces, 15(6), 28-46.

Fisher, M. L. (1997, March-April). What is the right supply chain for your product?. Harvard Business Review, 105-116.

Foote, P., \& Krishnamurthi, M. (2001) Forecasting using data warehousing model: Wal-Mart's experience. The Journal of Business Forecasting, 20(3), Fall, 13-17.

Godfrey, P. C., Illes, L. M., \& Berry, G. R. (2005, September). Creating breadth in business education through service learning. Academy of Management Learning \& Education, 4(3), 309-323.

Hamel, G. (1996). Strategy as revolution. Harvard Business Review, 74(4), 69-81.

Heizer, J., \& Render, B. (2011). Operations Management (10th ed.). Prentice Hall, Inc., Upper Saddale River, N.J.

Jain, J., Dangayach, G. S., Agarwal, G., \& Banerjee, S. (2010). Supply chain management: literature review and some issues. Journal of Studies on Manufacturing, 1(1), 11-25.

Kotler, P., \& Armstrong, G. (2010). Principles of Marketing (13th ed.). Pearson: Prentice-Hall.

Kotler, P., \& Keller, K. (2008). Marketing Management (13th ed.). Pearson: Prentice-Hall.

Lee, H. L. (2004). The triple-A supply chain. Harvard Business Review, 82(10), 102-113.

Liesz, T. (2002). Really modified Du Pont analysis: five ways to improve return on equity. Proceedings of the SBIDA Conference.

Lim, J., Richardson, V., \& Roberts, T. (2004). Information technology investment and firm performance: a meta-analysis. Proceedings of the 37th Hawaii international conference on system sciences.

Lorange, P., \& Rembiszewski, J. (2015, February 1). Great to gone: the new approach to growth and profitability that business schools need. EFMD Insights into Business Education: Case Studies From Business Schools World, (4), 29-32.

McMurray, S., Dutton, M., McQuaid, R., \& Richard, A. (2016). Employer demands from business graduates. Education + Training, 58(1), 112-132.

Mingers, J. (2015, April 1). Helping business schools engage with real problems: The contribution of critical realism and systems thinking. European Journal of Operational Research, 242(1), 216-331.

Mintzberg, H., \& Gosling, J. (2002). Educating managers beyond borders. Academy of Management Learning \& Education, 1(1), 64-76.

Pharr, S. W. (2000). Foundational considerations for establishing an integrated business common core curriculum. Journal of Education for Business, 76(1), 20-23. 


\section{$\triangle 1$ Macrothink}

International Journal of Accounting and Financial Reporting ISSN 2162-3082

Pharr, S. W., Morris, J.S., Stover, D., Byers, C. R., \& Reyes, M. G. (1998). The execution and evaluation of an integrated business common core curriculum. Journal of General Education, 47, 166-182.

Prime Revenue. (2017). Retrieved from http://www.primerevenue.com/

Raufflet, E. (2013). Integrating sustainability in management education. Humanities, 2, 439-448.

Reilly R., \& Gupta, U. (2015). An Introduction to Management Systems (1st ed.). Kendall Hunt Publishing, Dubuque, IA.

Reynolds, J. (Ed.) (2004). Retail strategy: the view from the bridge. London: Butterworth-Heinemann.

Robbins, S. P., \& DeCenzo, D. A. (2008). Fundamentals of Management (6th ed.). Pearson Prentice Hall, Inc., Upper Saddale River, N.J.

Schermerhorn, J. R. (2010). Exploring Management (2nd ed.). John Wiley \& Sons, Inc, Hoboken, N. J.

Shaildullina, A. R., Pavlova, N. A., Minsabirova, V. N., Burdukovskaya, E. A., Yunusova, A. B., Letyaev, V. A., \& Afanasev, A. S. (2015). Integration process in education: classification of integration types. Review of European Studies, 7(4).

Simchi-Levi, D., Kaminsky, P., \& Simchi-Levi, E. (2003). Designing and Managing the Supply Chain (2nd ed.). New York, NY. McGraw-Hill.

Stevenson, W. (2009). Operations Management (10th ed.). McGraw Hill Higher Education, New York, N.Y.

Swink, M., \& Way, M. H. (1995). Manufacturing strategy: propositions, current research, renewed directions. International Journal of Operations and Production Management, 1597, 4-26.

Wheelwright, S. C. (1984). Manufacturing strategy: defining the missing link. Strategic Management Journal, 5(1), 77-91.

\section{Copyright Disclaimer}

Copyright for this article is retained by the author(s), with first publication rights granted to the journal.

This is an open-access article distributed under the terms and conditions of the Creative Commons Attribution license (http://creativecommons.org/licenses/by/4.0/) 